Papers and Proceedings of the Royal Society of Tasmania, Volume 111, 1977

(ms. received 22.12 .1976$)$

\title{
OBSERVATIONS ON THE FOOD OF FRESHWATER FISH FROM THE COAL AND JORDAN RIVERS, TASMANIA
}

\author{
by P.S. Lake ${ }^{a}$ and G. Bennison ${ }^{b}$ \\ Department of Zoology, University of Tasmania \\ (a) now Department of Zoology, Monash University, Clayton, Victoria \\ (b) now 4 Fellows Road, Hughesdale, Victoria
}

(with five tables)

\section{ABSTRACT}

The Coal and the Jordan Rivers are two slow-flowing rivers in south-eastern Tasmania. Details are given of the stomach contents of brown trout Salmo tmita Linnaeus, English perch Perca fluviatilis Linnaeus, short-finned ee1s Anguizia australis occidentalis Schmidt and Tasmanian smelt Retropinna tasmaniea McCulloch collected from the Coal River and of the stomach contents of brown trout, English perch, tench, short-finned eels, freshwater flathead Pseudaphritis urvizi (Cuvier and Valenciennes) and galaxiids Galaxias maculatus (Jenyns) collected from the Jordan River.

\section{INTRODUCTION}

The food of trout in Australia has been studied by Mckeown (1934a, 1934b, 1936, 1937, 1955), Evans (1942), Butcher (1945, 1946), Wilson (1966) and Knott (1973). However, there are few published data on the food of native freshwater fish or even of non-sa1monid introduced fish. Butcher $(1945,1946)$ examined the food of Macquarie perch, Macquaria australasica (Cuvier \& Valenciennes), English perch, Perca fluviatilis Linnaeus, blackfish, Gadopsis mamoratus (Richardson) and Galaxias maculatus (Jenyns). Mckeown (1934a) recorded the food of six Macquarie perch and brief non-quantitative descriptions of the food of some native and introduced freshwater fish of New South Wales are given by Lake (1959). Recently Pollard (1973) has provided a detailed account of the diet of land-locked Galaxias maculatus in Lake Modewarre, Victoria. In Tasmania the food of tench Tinca tinca (Linnaeus) has been studied by Weatherley (1962) and the food of a few specimens of the Tasmanian blackfish (G. mamoratus) has been recorded by Knott (1973).

There are no published accounts of the food of freshwater eels in Australia, despite the fact that eels, mainly short finned eels Anguizla australis occidentalis Schmidt, are common in coastal streams of south-eastern Australia and Tasmania and are considered by many anglers to damage the trout fisheries. Such a situation contrasts with the situation in New Zealand where there has been a number of studies of the food of freshwater eels mainly of the long finned eel Anguizza dieffenbachi Gray (e.g. Cairns 1942, A1len 1951, Burnet 1952, 1969, Hopkins 1965, 1970, Cadwa11ader 1975). Cairns (1942) and Burnet (1952) have shown that the diets of the long finned eel and the short finned eel are rather similar.

The present study is of a preliminary nature only and provides some data on the food of introduced brown trout Salmo trutta Linnaeus, English perch and tench and of the native short finned ee1, freshwater flathead Pseudaphritis urvilzi (Cuvier $q$ valenciennes), Tasmanian smelt Retropinna tasmanica McCulloch and Galaxias maculatus.

\section{THE RIVERS OF INTEREST}

The Coal River rises near Tunnack, flows westward for about $24 \mathrm{~km}$ to pass close to Lake Tiberias, then flows southward for about $56 \mathrm{~km}$ to enter the sea at Pittwater, near 
Richmond.

The Jordan River is the outflow of Lake Tiberias and flows in a north-westerly direction to Jericho where it then flows in a southerly direction for about $80 \mathrm{~km}$ through Melton Mowbray, Broadmarsh and Brighton to enter the Derwent estuary near Bridgewater.

Data on the water chemistry of the five sampling sites on the Coal River where fish were collected are presented in table 1.

Data on the water chemistry of four localities on the Jordan River are given in table 2 .

The Jordan River is both more alkaline and more saline than the Coal River. Both rivers may be regarded as "hard" with respect to calcium concentrations (Williams 1964).

\section{MATERTALS AND METHODS}

Fish were collected with an electro-fishing machine, which was constructed from a design by Dr R.H.K. Mann of the Freshwater Biological Association, U.K. (pers. comm.). The design of the control switch circuitry was modified from that in the original plan. Power was provided by a Honda E800 U generator and the A.C. current was rectified to either a 50 P.P.S. or 100 P.P.S. pulsed D.C. current.

The fish from the five sampling sites of table 1 were collected on 10 October and 24 October 1974. Two other fish samples from the Coal River were collected on 3 October 1975 and 26 March 1976. Both of these samples were collected about three km upstream from Campania near the Brown Mountain Road station of table 1 . Fish were collected from the Jordan River on 2 April 1976 near the property of "Cliftonvale" where the road from Elderslie crosses the river.

After capture the fish were individually labelled with a metal tag and preserved in five per cent neutral formalin. Fish longer than about $100 \mathrm{~mm}$ were slit along the ventral surface to allow formalin to enter the body cavity. Stomachs were later removed from the fish and the stomach contents identified and recorded using the numerical method (Windell 1971).

\section{RESULTS}

Details of the stomach contents of the fish collected in the Coal River on the three separate occasions, October 1974, October 1975 and March 1976, are given in table 3. At the times of sampling in October 1974 and March 1976 the river was clear and at the normal low summer level, while in October 1975 the Coal River was turbid and fast flowing after a heavy spate.

Although the collection dates differed and the conditions of the river at the times of the three collections differed, to give an overall indication of the diets of the various fish species collected from the Coal River, the data of the three collections are combined in table 4.

The porportion of empty stomachs of each fish species captured from the Coal River varied considerably. The incidence of empty stomachs was low in trout, perch and smelt whereas in tench and eels the incidence was much higher.

In the Coal River, amphipods (Austrochiztonia australis (Sayce) and Paracalziope fluviatizis (Thomson)) formed the main part of the diets of the three most abundant fish, namely trout, eels and perch. Trichopteran larvae, mostly of the family Leptoceridae, constituted an important part of the diet of trout and eels, while Ephemeroptera were prominent in the diets of perch and eels. Their habit of feeding in the still parts of the river is reflected in the diet of tench, with gastropods and ostracods, both found in still, weedy stretches of the river, being important in the diet. Although only a few smelt were collected, the data suggest that chironomid larvae are an important food for this species.

Details of the stomach contents of fish collected from the Jordan River are given in table 5. As in the Coal River samples, eels and tench from the Jordan River had a relatively high incidence of empty stomachs compared with fish such as trout and perch. There were some notable differences between the food of fish from the Jordan and 


\section{P.S. Lake and G. Bennison}

Coal Rivers. In the Jordan River aquatic dipteran larvae, mostly chironomids, are important in the diets of trout, eels and galaxiids, although trichopteran larvae form an important part of the diet of trout, eels and tench in both rivers.

\section{DISCUSSION}

In the following discussion the conclusions can only be of a tentative nature since the numbers of fish examined, especially of Retropinna tasmanica, Pseudaphritis urvilli and Galaxias maculatus, were relatively low. All fish were collected in early-to midafternoon. The tench and eels were notable for the relatively high proportion of fish with empty stomachs which may be due to nocturnal feeding habits. In New Zealand streams, eels have been reported to be more active and to feed at night (Cairns 1942, Cadwallader 1975) and Burnet (1952) also suggested that eels, especially large eels, are spasmodic feeders. Tench may also be largely nocturnal feeders since Weatherley (1962) observed that at night tench schools disperse and individuals swim "in apparent independence of each other". This activity may be related to nocturnal feeding.

In both rivers the basic food of trout consisted of trichopteran larvae (especially the cased eruciform larvae), decapod shrimps (Paratya tasmaniensis Riek) and amphipods (Austrochiltonia australis and Paracalliope fluviatilis). In the Jordan River aquatic dipteran larvae (mostly Chironomidae) were the dominant food.

Eels appear to be opportunistic in their choice of food. amphipods and trichopteran larvae were the most important food items, whereas in the Jordan River trichopteran larvae and dipteran larvae were the most important food items. In both rivers, eels closely resemble trout in the major food items eaten. Whether interspecific competition is severe between the two species is difficult to say from such a preliminary study. In both rivers, trout and eels occupy different habitats; trout prefer areas where there is some current, whereas eels prefer weedy areas and areas with sunken logs and plant debris. Thus, although they may eat similar food items, they may largely avoid competition by inhabiting and feeding in different habitats in the same river, as suggested by Burnet (1969).

Butcher (1945) and Lake (1959) in Victoria and New South Wales respectively, found that the food of perch $P$. fluviatilis consisted mainly of Crustacea and insect larvae, mainly Trichoptera. In the Coal River, amphipods were the major food of perch while in the Jordan River trichopteran larvae were the most important food. Perch were mainly caught in still and slow-flowing parts of the rivers, often in weedy stretches.

Tench were only collected in weedy, still sections of the rivers; a habitat they prefer (Weatherley 1962). In the Coal River gastropods were their major food, while trichopteran larvae were their major food in the Jordan River. The food of tench from the two rivers is similar to that recorded by weatherley (1959).

The food of the small number of Tasmanian smelt examined consisted predominantly of dipteran (Chironomidae) and trichopteran larvae. Lake (1971) reported that mainland Australian species of Retropinna feed on algae and plankton. In New Zealand Allen (1951) found that the food of a smal1 sample of the smelt Retropinna osmeroides Hector was dominated by chironomid larvae and pupae. He concluded that the food of smelt in rivers is similar to that of young trout and that food competition may occur between the two species.

Pseudaphritis urvilzi was only collected in the Jordan River from sections with a gravel substrate and a moderate current flow. Although only a few fish were examined it appears that $P$. urvilzi is carnivorous with trichopteran larvae, Paratya tasmaniensis, amphipods and gastropods forming the major part of the diet.

The sample of Gazaxias macuzatus from the Jordan River fed on Cladocera, aquatic dipteran larvae (mainly Chironomidae), Hymenoptera (Formicidae) and Amphipoda in decreasing order of importance. Pollard (1973) investigated the diet of a land-locked population of $G$. maculatus inhabiting Lake Modewarre in south-western Victoria and found that the diet consisted mainly of amphipods, chironomid larvae and small crustaceans (copepods, cladocerans, ostracods). Butcher (1946), Allen (1951) and McDowall (1968) found that the diet of stream-dwelling G. macuzatus was dominated by dipterans (mainly chironomid larvae and pupae). 
Food of Freshwater Fish, Coal and Jordan Rivers, Tas.

This preliminary study indicates that the different fish species in the Coal and Jordan Rivers share a common food resource. For example, in the Coal River amphipods form an important part of the diets of trout, perch and eels, whereas in the Jordan River trichopteran larvae (eruciform) form an important part of the diets of trout, perch, eels, tench and freshwater flathead. It is conceivable that interspecific competition for food is occurring in the rivers, for example between trout and smelt, perch and trout.

\section{ACKNOWLEDGEMENTS}

We wish to thank the Freshwater Ecology (Zoology III) students of 1975 and 1976 for their hard work in collecting the fish and examining the stomach contents and Messrs R.B. Mawbey, R. Norris, K.H. Lim and R. Sloane and Dr R. Gaymer for invaluable assistance in the execution of the practical exercises.

We are grateful to the Inland Fisheries Commission, Hobart, for permission, to electro-fish in the Coal and Jordan Rivers. We would also like to thank Dr. P. Cadwallader, Fisheries and Wildlife Division, Ministry for Conservation, Snobs Creek, Victoria, and $\mathrm{Mr}$ W. Fulton, Inland Fisheries Commission, Hobart, for very thorough and constructive criticism of a draft manuscript.

\section{REFERENCES}

Allen, K.R., 1951: The Horokiwi stream. A study of a trout population. Fish. Bull. N.Z., $10,1-231$.

Buckney, R.T. and Tyler, R.A., 1973: Chemistry of Tasmanian inland waters. Int. Rev. ges. Hydrobioz. Hydrogr., 58, 61-78.

Burnet, A.M.R., 1952: Studies on the ecology of the New Zealand long-finned eel, Anguizza dieffenbachi Gray. Aust. J. Mar. Freshwat. Res., 3, 32-63.

, 1969: A study of the inter-relation between eels and trout, the invertebrate fauna and the feeding habits of the fish. Fish. Tech. Rep. N.2., 36 $1-23$.

Butcher, A.D., 1945. The food of indigenous and non-indigenous fish in victoria with special reference to trout. Pomph. Vic. Dept Fish \& Game, 4:1-48.

, 1946: THE FRESHWATER FISH OF VICTORIA AND THEIR FOOD. Vic. Dept Fish ६ Game, Melbourne. pp. 1-56.

Cadwallader, P.L., 1975: Feeding relationships of galaxiids, bullies, eels and trout in a New Zealand River. Aust. J. Mar. Freshwat. Res., 26, 299-316.

Cairns, D., 1942: Life history of the two species of freshwater eel in New Zealand. II. Food and interrelationships with trout. N.Z. J. Sei. Technol., 23, 132-148.

Evans, J.W., 1942: THE FOOD OF TROUT IN TASMANIA. The Salmon and Freshwater Fisheries Commission, Hobart.

Hopkins, C.L, 1965: Feeding relationships in a community of freshwater fish. N.?., J. Sei. Technol., 8, 149-157.

, 1970: Some aspects of the bionomics of fish in a brown trout nursery stream. Fish. Res. Bulz. N.\%. (N.S.), 4, 1-37.

Knott, B., 1973: What Tasmanian trout eat now and what will they eat next? In THE TASMANIAN TROUT, by D. Gilmour. Mary Fisher Bookshop, Launceston Tasmania. 
pp. $244-265$.

Lake, J.S., 1959: The freshwater fishes of New South Wales. N.S.W. State Fish Res. BuZZ., 5, 1-19.

, 1971: FRESHWATER FISHES AND RIVERS OF AUSTRALIA. Thomas Nelson

(Australia) Ltd., Melbourne and Sydney.

McDowall, R.M., 1968: Galaxias maculatus (Jenyns), the New Zealand whitebait. Fish. Res. BuZZ. N.Z. (N.S.), 2, 1-84.

McKeown, K.C., 1934a: Notes on the food of trout and Macquarie perch in Australia. Rec. Aust. Mus., 19, 141-152.

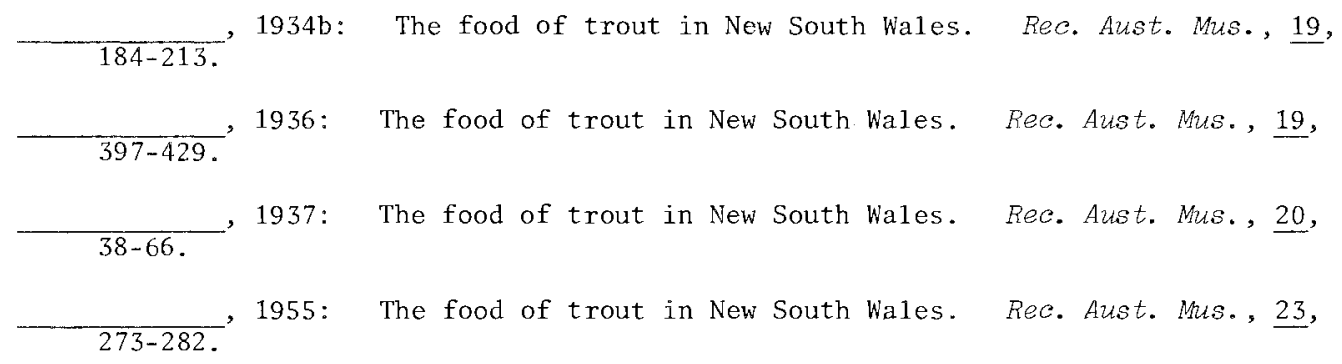

Pollard, D.A., 1973: The biology of a landlocked form of the normally catadromous Sa1moniform fish GaZaxias maculatus (Jenyns). V. Composition of the diet. Aust. J. Mar. Freshwat. Res., 24, 281-295.

Weatherley, A.H., 1959: Some features of the biology of the tench Tinca tinca (Linnaeus) in Tasmania. J. Anim. Ecol., 28, 73-87.

, 1962: Notes on distribution, taxonomy and behaviour of tench Tinca tinea (L.) in Tasmania. Ann. Mag. Nat. Hist. Ser. 13, 4, 713-719.

Williams, W.D., 1964: Sone chemical features of Tasmanian inland waters. Aust. J. Mar. Freshwat. Res., 15, 107-122.

Wilson, J.H., 1966: The food of trout in Great Lake. Aust. Soc. Limnoz. News2., 5, 21-23.

Winde11, J.T., 1971: Food analysis and rate of digestion. In Ricker, W.E., (Ed.): METHODS FOR ASSESSMENT OF FISH PRODUCTION IN FRESH WATERS. 2nd edn. Blackwells Sci. Pub., Oxford. pp. 215-226. 
TABLE 1

Results of chemical analyses of Coal River water in October 1974

\begin{tabular}{|c|c|c|c|c|c|c|c|c|c|c|c|}
\hline Locality & A & B & $\mathrm{pH}$ & $\mathrm{Na}^{+}$ & $\mathrm{K}^{+}$ & $\mathrm{Ca}^{++}$ & $\begin{array}{l}\mathrm{Mg}^{++} \\
\mathrm{eq} / 1\end{array}$ & $\mathrm{Cl}^{-}$ & $\mathrm{HCO}_{3}^{-}$ & $\mathrm{SO}_{4}^{-}$ & $\begin{array}{l}\text { Alkal- } \\
\text { inity } \\
\mathrm{mg} / \mathrm{l}\end{array}$ \\
\hline Baden & 20 & 185 & 7.9 & 1,350 & 40 & 880 & 270 & 920 & 850 & 320 & 47.5 \\
\hline Brandy Bottom & 34 & 247 & 8.6 & 1,430 & 50 & 1,900 & 430 & 1,400 & 1,110 & 310 & 67.5 \\
\hline Craigbourne $\mathrm{Rd}$ & 46 & 270 & 8.5 & 1,520 & 51 & 1,900 & 510 & 1,610 & 1,230 & 230 & 85.0 \\
\hline $\begin{array}{l}\text { Brown Mountain } \\
\text { Road }\end{array}$ & 58 & 306 & 8.6 & 1,570 & 54 & 1,880 & 530 & 1,780 & 1,280 & 270 & 100.0 \\
\hline Laburnum Park & 67 & 298 & 8.0 & 1,630 & 49 & 1,380 & 530 & 1,720 & 1,310 & 270 & 100.0 \\
\hline
\end{tabular}

A kilometres downstream from source

B $\quad \mathrm{K}_{18}{ }^{\mu \mathrm{S}} \mathrm{cm}^{-1}$

TABLE 2

Results of the analyses of some chemical features of Jordan River water

\begin{tabular}{|c|c|c|c|c|c|c|c|c|c|}
\hline Loca1ity & $\begin{array}{c}\text { Total } \\
\text { dissolved } \\
\text { solids } \\
\text { p.p.m. }\end{array}$ & $\mathrm{pH}$ & $\mathrm{Na}^{+}$ & $\mathrm{K}^{+}$ & $\mathrm{Ca}^{++}$ & $\begin{array}{l}\mathrm{Mg}^{++} \\
\mathrm{q} / \mathrm{I}\end{array}$ & $\mathrm{C} 1^{+}$ & $\mathrm{HCO}_{\overline{3}}$ & $\begin{array}{l}\text { Alkalinity } \\
\text { p.p.m. }\end{array}$ \\
\hline Lake Tiberias (1) & 463.6 & 7.6 & 4350 & 1024 & 130 & 2166 & 7360 & 2160 & \\
\hline $\begin{array}{c}\text { Jordan River } \\
\text { (Jericho) }\end{array}$ & $744-1345$ & $7.4-8.1$ & - & - & - & - & - & - & $194-396.5$ \\
\hline $\begin{array}{c}\text { Jordan River } \\
\text { (Pontville) }\end{array}$ & 644 & 8.0 & - & - & - & - & - & - & 222 \\
\hline $\begin{array}{c}\text { Jordan River } \\
\text { (Brighton) }\end{array}$ & $622-1072$ & $7.8-8.0$ & - & - & - & - & - & - & $85.4-322.0$ \\
\hline
\end{tabular}
(1) Buckney and Tyler (1973)
(2) Williams (1964) 
TABLE 3

Stomach contents of fish collected from the Coal River in October 1974, October 1975 and March 1976

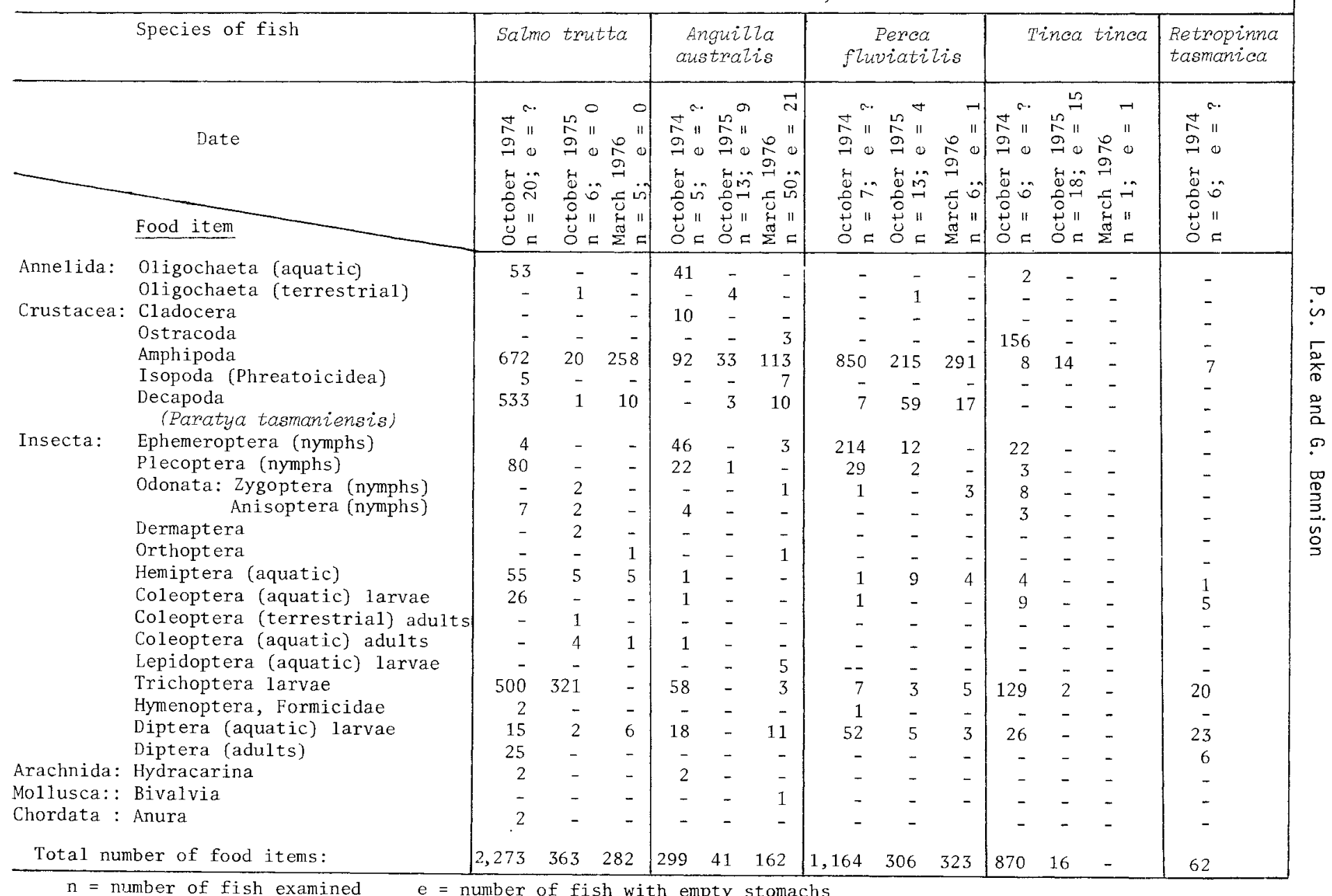


Summary of stomach contents of fish captured from Coal River in October 1974, October 1975 \& March 1976

\begin{tabular}{|c|c|c|c|c|c|c|}
\hline & & $\begin{array}{c}\text { Salmo } \\
\text { trutta } \\
\% \\
\mathrm{n}=30\end{array}$ & $\begin{array}{c}\text { Anguizla } \\
\text { austrazia } \\
\% \\
\mathrm{n}=68\end{array}$ & $\begin{array}{c}\text { Perca } \\
\text { fluviatizis } \\
\% \\
\mathrm{n}=36\end{array}$ & $\begin{array}{c}\text { Tinea } \\
\text { tinca } \\
\% \\
\mathrm{n}=25\end{array}$ & $\begin{array}{c}\text { Retropinna } \\
\text { tasmanica } \\
\% \\
\mathrm{n}=6\end{array}$ \\
\hline Anne1ida: & $\begin{array}{l}\text { Oligochaeta (aquatic) } \\
\text { o1igochaeta (terrestria1) }\end{array}$ & $\begin{array}{r}1.32 \\
.03\end{array}$ & $\begin{array}{r}8.17 \\
.80\end{array}$ & -.05 & $\begin{array}{l}0.23 \\
-\end{array}$ & - \\
\hline Crustacea: & $\begin{array}{l}\text { C1adocera } \\
\text { Ostracoda } \\
\text { Amphipoda } \\
\text { Isopoda (Phreatoicidea) } \\
\text { Decapoda } \\
\quad \text { (Paratya tasmaniensis) }\end{array}$ & $\begin{array}{r}- \\
- \\
32.55 \\
.17 \\
18.64\end{array}$ & $\begin{array}{r}1.99 \\
.60 \\
47.41 \\
1.39 \\
2.59\end{array}$ & $\begin{array}{l}- \\
- \\
75.62 \\
- \\
4.63\end{array}$ & $\begin{array}{l}-\overline{17.61} \\
2.48 \\
- \\
-\end{array}$ & $\begin{array}{l}- \\
- \\
11.29 \\
-\end{array}$ \\
\hline Insecta: & $\begin{array}{l}\text { Ephemeroptera (nymphs) } \\
\text { Plecoptera (nymphs) } \\
\text { Odonata: } \\
\text { Zygoptera (nymphs) } \\
\text { Anisoptera (nymphs) } \\
\text { Dermaptera } \\
\text { Orthoptera } \\
\text { Hemiptera (aquatic) } \\
\text { Coleoptera (aquatic) larvae } \\
\text { Coleoptera (terrestrial) } \\
\text { adults } \\
\text { Coleoptera (aquatic) adults } \\
\text { Lepidoptera (aquatic) larvae } \\
\text { Trichoptera İarvae } \\
\text { Hymenoptera, Formicidae } \\
\text { Diptera (aquatic) larvae } \\
\text { Diptera (adults) }\end{array}$ & $\begin{array}{r}.14 \\
2.74 \\
.10 \\
.31 \\
.06 \\
.03 \\
2.23 \\
.89 \\
.03 \\
.17 \\
- \\
28.14 \\
.06 \\
.79 \\
.86\end{array}$ & $\begin{array}{r}9.76 \\
4.58 \\
.40 \\
.80 \\
-\quad \\
.20 \\
.20 \\
.20 \\
- \\
.20 \\
1.00 \\
12.15 \\
- \\
5.78 \\
-\end{array}$ & $\begin{array}{l}12.60 \\
1.73 \\
.22 \\
- \\
- \\
- \\
.78 \\
.05 \\
- \\
- \\
- \\
.84 \\
.05 \\
3.35 \\
-\end{array}$ & $\begin{array}{l}2.48 \\
.33 \\
.90 \\
.34 \\
- \\
- \\
.45 \\
1.02 \\
- \\
- \\
- \\
14.79 \\
- \\
2.93 \\
-\end{array}$ & $\begin{array}{l}- \\
- \\
- \\
- \\
- \\
- \\
1.61 \\
8.06 \\
- \\
- \\
- \\
32.26 \\
- \\
37.09 \\
0.67\end{array}$ \\
\hline Arachnida: & Hydracarina & .06 & .40 & - & - & - \\
\hline Mollusca: & $\begin{array}{l}\text { Bivalvia } \\
\text { Gastropoda }\end{array}$ & 10.07 & $\begin{array}{r}.20 \\
1.00\end{array}$ & -.05 & $\overline{56.43}$ & $\begin{array}{l}- \\
-\end{array}$ \\
\hline Amphibia: & Arura & .06 & - & - & - & - \\
\hline
\end{tabular}


TABLE 5

Details of the stomach contents of fish collected from the Jordan River on 2 April 1976

\begin{tabular}{|c|c|c|c|c|c|c|c|c|c|c|c|c|c|}
\hline & & $\begin{array}{l}S a \\
S t \\
\mathrm{n} \\
\mathrm{e}\end{array}$ & $\begin{array}{l}2 m o \\
\text { wutta } \\
=58 \\
=9 \\
\quad \frac{0}{6}\end{array}$ & $\begin{array}{c}\text { Ang? } \\
\text { aust } \\
\mathrm{n} \\
\mathrm{e}\end{array}$ & $\begin{array}{l}i z z a \\
\text { razis } \\
=91 \\
=50 \\
\%\end{array}$ & $\begin{array}{r}E \\
\text { flut } \\
\end{array}$ & $\begin{array}{l}\text { erca } \\
\text { iatizis } \\
=22 \\
=5 \\
\%\end{array}$ & & $\begin{array}{c}\text { nea } \\
\text { inca } \\
=27 \\
=17 \\
\\
\%\end{array}$ & $\begin{array}{c}\text { Pseude } \\
\text { urn } \\
\mathrm{n} \\
\mathrm{e}\end{array}$ & $\begin{array}{l}\text { ohritis } \\
\text { izzi } \\
8 \\
4 \\
\%\end{array}$ & $\begin{array}{c}\text { Gal } \\
\operatorname{mac} \\
\mathrm{n} \\
\mathrm{e}\end{array}$ & $\begin{array}{l}\text { axias } \\
\text { ulatus } \\
=8 \\
=1 \\
\%\end{array}$ \\
\hline Annelida: 0 & Oligochaeta (aquatic) & 1 & .22 & - & - & - & - & - & - & - & & & - \\
\hline Crustacea: & $\begin{array}{l}\text { C1adocera } \\
\text { Ostracoda } \\
\text { Amphipoda } \\
\text { Isopoda (Phreatoicidea) } \\
\text { Decapoda } \\
\quad \text { (Paratya tasmaniensis) }\end{array}$ & $\begin{array}{r}2 \\
- \\
72 \\
1 \\
36\end{array}$ & $\begin{array}{c}.43 \\
- \\
15.65 \\
.22 \\
7.82\end{array}$ & $\begin{array}{r}3 \\
- \\
10 \\
1 \\
11\end{array}$ & $\begin{array}{r}3.37 \\
- \\
11.23 \\
1.23 \\
12.36\end{array}$ & $\begin{array}{r}3 \\
3 \\
2 \\
13\end{array}$ & $\begin{array}{r}4.28 \\
4.28 \\
2.85 \\
18.57\end{array}$ & $\begin{array}{l}- \\
- \\
- \\
- \\
-\end{array}$ & $\begin{array}{l}- \\
- \\
- \\
- \\
-\end{array}$ & $\begin{array}{r}- \\
- \\
7 \\
- \\
12\end{array}$ & $\begin{array}{c}- \\
19.44 \\
- \\
33.33\end{array}$ & $\mid \begin{array}{r}10 \\
1 \\
2 \\
- \\
-\end{array}$ & $\begin{array}{r}45.45 \\
4.54 \\
9.09 \\
- \\
-\end{array}$ \\
\hline Insecta: & $\begin{array}{l}\text { Thysanura } \\
\text { Ephemeroptera (nymphs) } \\
\text { Hemiptera (aquatic) } \\
\text { Hemiptera (terrestrial) } \\
\text { Coleoptera larvae (aquatic) } \\
\text { Coleoptera adults (aquatic) } \\
\text { Coleoptera adults (terrestrial) } \\
\text { Trichoptera larvae (eruciform) } \\
\text { Trichoptera larvae (campoderiform) } \\
\text { Trichoptera adults } \\
\text { Hymenoptera Formicidae } \\
\text { Diptera larvae (aquatic) } \\
\text { Diptera larvae (terrestrial) } \\
\text { Diptera adults }\end{array}$ & $\begin{array}{r}9 \\
4 \\
10 \\
1 \\
- \\
1 \\
3 \\
59 \\
44 \\
4 \\
14 \\
169 \\
4 \\
13\end{array}$ & $\begin{array}{r}1.95 \\
.87 \\
2.17 \\
.22 \\
- \\
.87 \\
.65 \\
12.83 \\
9.57 \\
.87 \\
3.04 \\
36.74 \\
.87 \\
2.83\end{array}$ & $\begin{array}{r}1 \\
- \\
4 \\
- \\
6 \\
- \\
- \\
21 \\
7 \\
- \\
- \\
12 \\
12 \\
-\end{array}$ & $\begin{array}{c}1.23 \\
- \\
4.49 \\
- \\
6.74 \\
- \\
- \\
23.59 \\
7.87 \\
- \\
- \\
13.48 \\
13.48 \\
-\end{array}$ & $\begin{array}{c}3 \\
- \\
7 \\
- \\
- \\
- \\
- \\
38 \\
- \\
- \\
1 \\
- \\
- \\
-\end{array}$ & $\begin{array}{c}4.28 \\
- \\
10.00 \\
- \\
- \\
- \\
- \\
54.29 \\
- \\
- \\
1.43 \\
- \\
- \\
-\end{array}$ & $\begin{array}{r}- \\
1 \\
- \\
- \\
44 \\
- \\
- \\
3 \\
- \\
- \\
-\end{array}$ & $\begin{array}{c}- \\
- \\
- \\
2.08 \\
- \\
- \\
91.66 \\
- \\
- \\
6.25 \\
- \\
- \\
-\end{array}$ & $\begin{array}{r}- \\
- \\
- \\
- \\
12 \\
2 \\
- \\
- \\
- \\
- \\
-\end{array}$ & $\begin{array}{c}- \\
2.77 \\
- \\
- \\
- \\
- \\
33.33 \\
5.55 \\
- \\
- \\
- \\
- \\
-\end{array}$ & $\begin{array}{l}- \\
- \\
1 \\
- \\
1 \\
- \\
- \\
2 \\
3 \\
- \\
1\end{array}$ & $\begin{array}{c}- \\
- \\
- \\
- \\
4.54 \\
- \\
4.54 \\
- \\
- \\
9.09 \\
13.64 \\
- \\
4.54\end{array}$ \\
\hline Arachnida: & Araneae & 1 & .22 & - & - & - & - & - & - & - & - & - & - \\
\hline $\begin{array}{l}\text { Moliusca: } \\
\text { Total nu }\end{array}$ & $\begin{array}{l}\text { Gastropoda } \\
\text { lumber of food items: }\end{array}$ & $\begin{array}{r}9 \\
460\end{array}$ & 1.95 & $\begin{array}{r}1 \\
89\end{array}$ & 1.23 & 70 & - & 48 & - & $\begin{array}{r}2 \\
36\end{array}$ & 5.55 & $\begin{array}{c}- \\
22\end{array}$ & - \\
\hline
\end{tabular}

